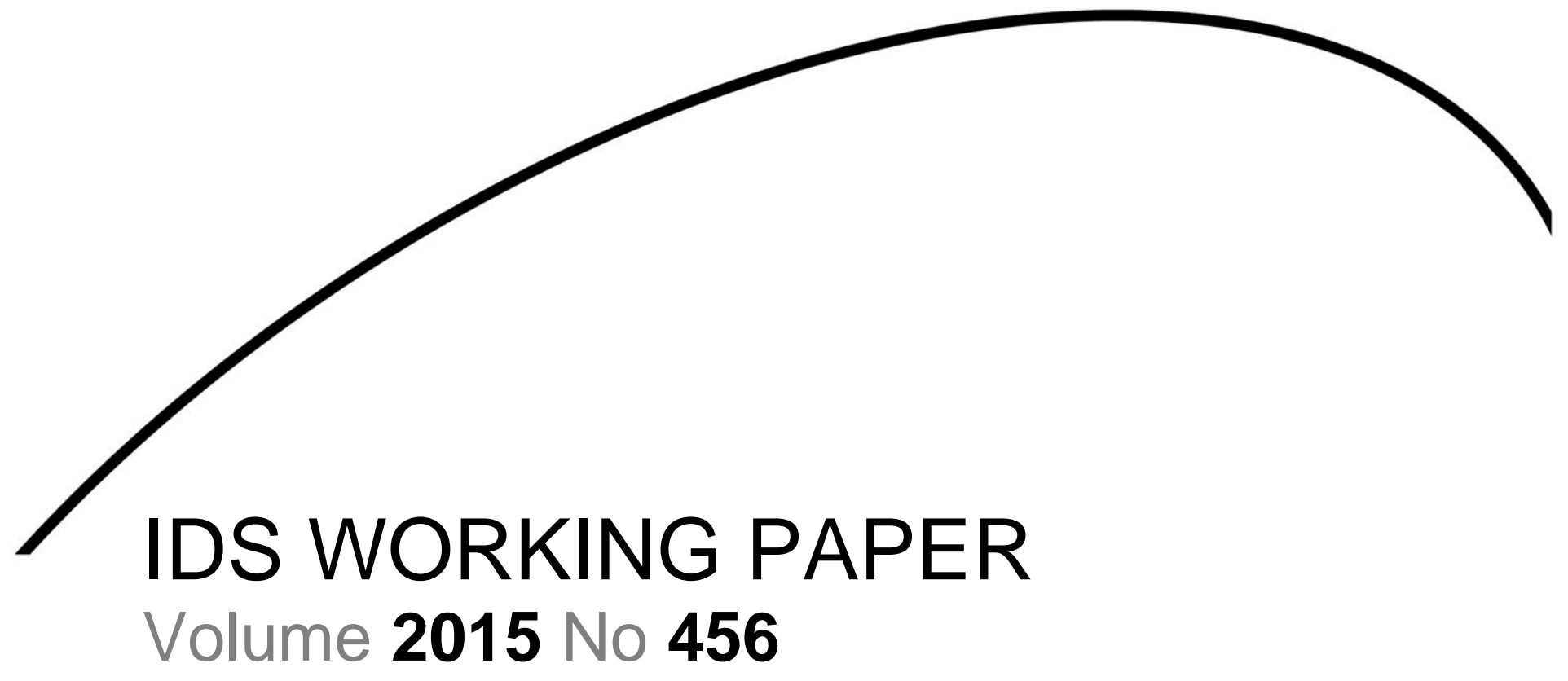

Decrypting Copts' Perspectives on Communal Relations in Contemporary Egypt through Vernacular Politics (2013-2014)

Mariz Tadros

May 2015 
Decrypting Copts' Perspectives on Communal Relations in Contemporary Egypt through Vernacular Politics (2013-2014) Mariz Tadros

First published by the Institute of Development Studies in April 2015

IDS Working Paper 456

(C) Institute of Development Studies 2015

ISSN: 2040-0209 ISBN: 978-1-78118-237-6

A catalogue record for this publication is available from the British Library.

All rights reserved. Reproduction, copy, transmission, or translation of any part of this publication may be made only under the following conditions:

- with the prior permission of the publisher; or

- with a licence from the Copyright Licensing Agency Ltd., 90 Tottenham Court Road, London, W1P 9HE, UK,

or from another national licensing agency; or

- under the terms set out below.

This publication is copyright, but may be reproduced by any method without fee for teaching or nonprofit purposes, but not for resale. Formal permission is required for all such uses, but normally will be granted immediately. For copying in any other circumstances, or for re-use in other publications, or for translation or adaptation, prior written permission must be obtained from the publisher and a fee may be payable.

\section{Available from:}

Communications and Engagement Unit, Institute of Development Studies, Brighton BN1 9RE, UK

Tel: +44 (0) 1273915637

E-mail: bookshop@ids.ac.uk

Web: www.ids.ac.uk/publications

IDS is a charitable company limited by guarantee and registered in England (No. 877338) 


\title{
Decrypting Copts' Perspectives on Communal Relations in Contemporary Egypt through Vernacular Politics (2013-2014)
}

\author{
Mariz Tadros
}

\section{Summary}

The study of vernacular allows for an examination of multiple forms of citizen voice, agency and embedded relations that contribute to understandings of securities and insecurities in highly distinct ways. This paper shows how the study of the vernacular contributed to decrypting the seeming paradox of how the Copts, Egypt's largest non-Muslim minority, experienced high levels of sectarian violence after 2013, yet reported an improvement in social status and social relations in comparison to the year under the reign of President Morsi. It identifies nine different ways in which securities/insecurities were conceptualised among Copts. The paper argues that by examining these vernacular conceptions, it is possible to explain what accounts for the discrepancy between the elitists' accounts of Copt support for authoritarianism and the differentiated, nuanced perspectives and positions on the ground. While such experiences are local, they shed light on shifting national and global configurations of power and forewarn of the kind of drivers that would serve as tipping points towards Coptic dissent.

Keywords: vernacular, Copts, critical security, Egypt, local governance, citizenship

Mariz Tadros is the co-leader of the Power and Popular Politics Cluster at the Institute of Development Studies, University of Sussex. She is the editor of the recently released book: Women in Politics (London, Zed Books, 2014) and the author of two monographs: Copts at the Crossroads: The Challenges of Building Inclusive Democracy in Egypt (American University in Cairo and Oxford University of America Press 2013); The Muslim Brotherhood in Contemporary Egypt: Democracy Redefined or Confined? (London, Routledge, 2012). Her research interests include religion in development, gender and development, political Islam, democratisation, unruly politics, and security. 


\section{Contents}

Summary 3

Acknowledgements 5

$\begin{array}{ll}\text { Introduction } & 6\end{array}$

1 Context conundrums $\quad 7$

2 Vernacular politics in practice $\quad 8$

$3 \quad$ Multiple experiences and framings of security in the vernacular 11

3.1 Insecurity as vulnerability to state-bolstered retribution 12

3.2 Safety from obtrusive aspects of unequal citizenship 17

3.3 Insecurity emanating from non-conformity as a non-veiled Christian woman 19

3.4 Feeling safe to walk the streets free from sexual harassment 20

3.5 Insecurity as susceptibility to individual and organised acts of thuggery (baltagah) 21

3.6 Insecurity as a consequence of lawlessness: Loss of haybat al dawla 22

3.7 National and territorial insecurity associated with the threat of terrorism 23

3.8 Insecurity as complete hopelessness for the future generation 24

3.9 Security/safety as peaceful harmonious living with the other 25

4 Conclusion $\quad 27$

$5 \quad$ Policy messages/issues 28

5.1 Policy messages on communal relations in Egypt 28

5.2 Policy messages for researchers, practitioners and activists' use of vernacular politics in heterogeneous societies with minority populations 29

$\begin{array}{ll}\text { References } & 31\end{array}$

Tables

Table 3.1 Typology of vernacular Coptic securities/insecurities 13

Table 3.2 What factor do you think most accounts for the increase in violence since $2011(\%)$ ? $\quad 15$

Table 3.3 Opinions on reconciliation with the Muslim Brotherhood (\%) 23

Table 3.4 Do you expect violence in the next two years will... (\%) 25 


\section{Acknowledgements}

This paper was commissioned by the Swiss Agency for Development and Cooperation (SDC) Democratisation, Decentralisation and Local Governance Network (DDLGN) programme that aims to address the questions of what accounts for improved majority/minority relations from the perspective of members of a religious minority who have been vulnerable to individual and group acts of violence for many decades. And what creates positive ruptures from violent, and tense social relations from the point of view of those who have experienced discrimination on the basis of their religious identity?

This paper is part of a series of contributions on sectarian relations in post-Mubarak Egypt. This paper is in follow-up to the examination of how the informal devolution of power after the ousting of President Mubarak in 2011 led to the empowerment of local leaders whose informal governance of communal tensions contributed to increased discriminatory practices against religious minorities whose production was funded by SDC DDLGN.

I am grateful to the SDC DDLGN programme for funding part of the research presented in this paper. I am also grateful for funding from the IDS programme on Strengthening Evidence-Based Policy under the theme Addressing and Mitigating Violence that supported fieldwork undertaken in 2013/2014 on political settlements and violence. This programme is funded by UK aid from the UK Government. I would also like to extend my gratitude to the British Academy mid-career fellowship for its generous support. I am indebted to Professor Robin Luckham and Dr Elizabeth Iskander for their astute and constructive feedback on an earlier draft of this paper. All disqualifiers apply. 


\section{Introduction}

The Copts, Egypt's largest non-Muslim minority, have experienced extremely high levels of sectarian violence since 2013, yet by and large, they are reporting an improvement in social status and social relations in comparison to the year under the reign of President Morsi. This paper examines what accounts for this seeming paradox by examining the multiple meanings of securities and insecurities through the study of the vernacular. The study of the vernacular is not only about capturing 'grassroots experiences' but an ontological project aimed at understanding narratives of how the shifting power configurations affected status and relations for Copts, differentiated along the lines of class, geography, gender, etc. This has a number of epistemological implications. Grassroots does not mean parochial, since many vernacular understandings of security/insecurity situate global developments and external interventions as central to understanding their predicament. Second, since the focus is on everyday realities, rather than policy-praxis connection, many of the narratives suggest citizens experiencing in positive and negative ways unintended outcomes of broader processes of transformation.

The second postulation that the paper makes is that the study of the vernacular is not only about capturing material intergroup inequalities, but also the cognitive perceptions of sources and consequences of securities/insecurities. One of the most deep-seated sources of insecurity for Copts has been the establishment of an Islamic state whose influence goes beyond formal governance and bolsters the powers of Islamist political movements and forces more broadly. Copts' fear towards and rejection of this model of governance is cognitive in the sense that it goes beyond material conditions, and emanates from a historical reading of their predicament over the centuries and their perceptions of their future.

The paper also questions the stereotypical view that emerges in recent external (and Egyptian) commentary about members of the Coptic community backing the authoritarian methods of the Sisi government, supporting 'strong' security and condoning violations of human rights. Such a reading doesn't correspond with members of that community's own vernacular understandings of the situation, which are much more subtle, qualified and rooted in their own experiences.

A fourth argument presented in the paper is that there is no any single vernacular understanding of security; there are several, this paper identifies at least nine distinct meanings. Some of them are shared and others differ between groups (between men and women, Copts and Muslims, etc.). They tend to be based upon quite specific and realistic appraisals of particular concerns or threats - of state repression, of criminal and gang violence, of sexual violence, of worsening interfaith relations.

Another case is made for understanding vernacular securities as involving the mediation of meaning not only within a group but through intergroup dialogue. Both Coptic and Muslim voices highlighted the need for an improvement of interfaith/community relations as a dimension of security.

While the case study focuses on Egypt, it is particularly relevant for other contexts marked by majority/minority unequal power dynamics, in particular of a religio-political nature, as it highlights the extreme disjuncture that can exist between elitists' and citizens' assessments of communal relations at a local level. It also provides a practical framework for using the vernacular to explore local citizen perspectives on social cohesion whilst being sensitive to the intersectionality of identities. Moreover, it shows in tangible practical terms both the significance of ideology in lived reality in mediating meanings to material conditions and to perceptions of the sources of securities and insecurities. 
The paper is organised in five sections. The first part provides some contextual background to sectarian dynamics in contemporary Egypt; the second discusses the relevance of the vernacular both in terms of framing and its methodological implications for this study; the third part presents the core findings of the study, presenting nine different understandings of security/insecurity. This is followed in the fourth part by some concluding reflections, and in the fifth part, a discussion of the policy implications.

\section{Context conundrums}

Egypt has been in the throes of tumultuous political upheaval having undergone two revolutionary ruptures within less than three years. After being reigned by one authoritarian ruler for 30 years (Mubarak), Egypt experienced three different leaderships in three years: the Supreme Council of Armed Forces from February 2011 to June 2012, President Morsi from the Muslim Brotherhood from July 2012 to June 2013, and interim president Mansour Adly from July 2013 to May 2014. Former Minister of Defence General Al-Sissi won the presidential elections and has ruled the country since then. During this period, the power configurations changed dramatically both on a macro and a micro level.

Egypt's 10 per cent Christian minority had a long history of experiencing sectarian violence during Mubarak's last decade of rule; however, the situation after 2011 became dramatically worse. The exacerbating factors were many, for example exclusionary and incompetent governance on the part of the ruling authorities, a security vacuum and a highly volatile political context (Tadros 2014). Since the overthrow of the Muslim Brotherhood-backed regime, pro-Morsi factions have targeted Christians in what seem to be organised and preorchestrated acts of vengeance. For example, on 14 August 2013, coinciding with the security crackdown on the pro-Morsi demonstrators in public squares in Cairo, pro-Morsi factions had attacked 64 places of worship belonging to Christians within 48 hours, not counting the attacks on private residential and business properties, individuals and organisations (Rahouma 2013).

In addition to the above, some of the religious-targeted forms of violence that emerged post2011 have persisted, such as the imposition of ransoms, kidnappings, unlawful occupation of property.

However, on 6 January 2015 Egyptians witnessed a scene that was the source of intense speculation vis-à-vis state-church-society relations. As is conventional practice, Pope Tawadrous, the Patriarch of the Coptic Orthodox Church and the largest of the three Christian denominations that exist in Egypt (followed by about 90 per cent of the Christian adherents) was presiding over Christmas Eve mass (Christmas day is celebrated on 7 January). In the middle of mass, President Al-Sissi made an unplanned appearance and made a short speech about how the country is big enough to accommodate everyone, amidst wild cheers and intense applause. When some of the Coptic participants shouted 'We love you Mr President' he interrupted his speech to shout 'And I love you too'. While former presidents had visited the Cathedral to wish Coptic Christians a merry Christmas (Ibrahim 2013), this was the first time that a president actually entered the church during prayers. The act is socially a faux pas vis-à-vis Muslim conservatives on account of these prayers being widely perceived as associated with infidel practices.

This vignette raised a number of conundrums that had their resonance in a deeply sceptical reading of the role and position of Copts in supporting military dictatorial regimes more broadly. The subtext to many of the critiques articulated in reaction to this vignette and in the months that followed was that Christians prefer dictatorial regimes with whom their church leaders can forge patronage relations. This has certainly been the viewpoint of a number of recent analyses presented by both Egyptian and Western writers, both Copts and non-Copts. 
Critics have written articles expressing shock, confusion and bewilderment at why Copts would support the current government led by Al-Sissi (Amin 2015; El Erian 2014; Fayek 2015; Hamzawy 2015). They point to the seeming Coptic amnesia towards the fact that AlSissi is the army, which is responsible for enacting the single worst act of state-perpetrated

violence against the Coptic minority that modern Egyptian history has witnessed. ${ }^{1}$ They question why Christians would allegedly support the return of a security state whose apparatus has failed to protect them from increasing vulnerability to sectarian attacks. They point to the church leadership role in supporting Al-Sissi, which they consider as a proxy for Christians' support for authoritarianism (Hamzawy 2015).

What will be argued below is that vernacular security studies may be ontologically and methodologically useful for understanding citizen agency at the local level, and exploring how Coptic citizenry on the ground conceive of sources and consequences of securities and insecurities. Significantly, such an approach shows how disconnected elite perspectives are from the pulse of the Coptic citizenry. It exposes how elitist narratives have tended to 'otherise' Copts; in other words, they are identified strictly in their capacity as members of a religious minority rather than agents with multiple identities, political orientations and perspectives. It also shows the limitations in narratives that conflate church leadership agency with the differentiated agencies of Copts. It also points to a failure to pursue a power analysis of the positioning and choices made by Coptic citizens at different junctures. This leads to a failure to take into account the conditions under which choices are made and how consequences are borne and explained.

\section{Vernacular politics in practice}

There is an ever-widening body of scholarship that has challenged the state-centric and international relations emphasis in security studies. Critiques have come from feminists who have critiqued the gender-blind nature of analysis and its assumed impartiality. Critiques have also come from development-centred quarters who have suggested that citizen entitlements should be at the centre of security studies. Critical security studies has also presented its own contestation of the language and the ontological underpinnings of mainstream security studies.

The human security paradigm made great strides in formulating security policy recommendations from the point of view of citizen entitlements. However, for scholars of the vernacular, it did not go far enough in conceptualising and understanding the agential dimensions of ordinary and marginalised citizens' engagement with security. Human security has also been characterised by a number of flaws with respect to allowing citizen voices to set the parameters of the security debate as opposed to having a framework against which citizen experiences were assessed and evaluated. The universalist frameworks have been questioned on account of their inability to capture citizen experiences across context and time.

One of the nascent streams in security studies, which are firmly grounded in agential lens and perspectives on security 'from below', is vernacular politics (Bubandt 2005; Jarvis and Lister 2013; Luckham and Kirk 2013). Bubandt (2005: 278) defines vernacular security as an attempt to combine 'a critical, discursive analysis of security with an anthropological

1 Peaceful protestors were shot, thrown into the river Nile and crushed by army vehicles as they frantically sought to flee what appeared to be systematic organised assaults. Much of it was captured on television footage and broadcast worldwide.

Ironically only three Christmas celebrations ago in January 2012, when representatives from the Supreme Council of Armed Forces (SCAF) had turned up at the Cathedral on 6 January to wish Christians a happy Christmas, members of the congregation, including those belonging to a Coptic social movement (the Maspero youth movement) had shouted out full blast to the military visitors in the middle of the service 'Down, down with the military regime! Down down with the assassins!' (Tadros 2013a). 
approach to the study of ontological uncertainty that does not reduce local ontologies of uncertainty to current political (and political science) conceptualizations of security'.

Ontological uncertainty in Bubandt's definition, which draws on the work of Anthony Giddens, is 'socially constructed anxiety that shapes pertinent kinds of danger, fears and concerns for a particular community at a particular time'. Such uncertainty is defined as ontological because 'it has an existential feature of the human condition; and yet it is always socially expressed because different societies have different ways of socially producing it, discursively portraying it, symbolically representing it and politically managing it. Uncertainty is in other words "onto-political"' (Bubandt 2005: 277).

This is perhaps where the vernacular diverges greatly from the human security paradigm in two critical ways. The human security paradigm's focus on citizen entitlement can operationally mean an examination of citizen experiences 'from below'. However, such analysis is underpinned by the goal of examining 'what does it mean for policymakers'. Ontologically, there is a danger that the process becomes one of distilling the perspectives of citizens so as to reduce them to the parts that fit into a particular framework for development intervention. Luckham and Kirk (2013: 341) caution 'security is not only systematically ambiguous, it is also politically contested and morally promiscuous. Everything depends on who speaks in the name of security and for whose security they speak'. Thus it is also crucial to ask from whom or what people are secured, and how security is provided or not as the case may be. Insufficient recognition to the subtleties of different understandings of securities may have several bearings on the kind of claims made on security threats being perceived by citizens and consequently what is considered as reflective of the kind of change that citizens aspire to see: 'most theorists and practitioners of security and development veer back and forth between security as a form of power and social ordering and security as an entitlement and potential form of empowerment. Often they presume to speak on behalf of vulnerable people and groups, whose own vernacular understandings of security they assume rather than investigate' (Luckham and Kirk 2013: 341).

Another important ontological departure from human security characterising the vernacular is the particular emphasis on the perceptions of citizens being just as important as their actual material conditions. The cognitive dimension of grappling with reality is what Bubandt terms 'socially constructed'. This paves the way for the examination of the circulation of rumours, threats, narratives that may influence people's perceptions of security/insecurity even when they are difficult to affirm or refute as real. If they seem real enough to citizens to influence their interpretation of relationships and conditions, then they need to be accounted for.

The third dimension of vernacular politics is the sensual or emotional dimension of how security is perceived: 'Security, in other words, deals with the problem of order and disorder, being both the ontological condition of order, in the sense of an absence of doubt, danger, risk and anxiety, and the political means of ensuring that order' (Bubandt 2005: 278).

Both Bubandt and Luckham and Kirk have proposed a 'bottom-up, actor-oriented and comparative analysis of the political creation of security'. Such an approach will pose both conceptual and methodological challenges since security is conceptualised and politically practised differently in different places and at different times (Bubandt 2005: 291). Identifying the plurality of how security is experienced on both individual and community levels is particularly challenging in view of the many contingencies that influence citizens' perspectives. These include, though they are not limited to, gender, class, age, geographic location, professional background and political orientation. While vernacular security entails a bottom-up approach, this does not suggest an exclusive focus on the local. Bubandt (2005: 291) suggests that 'vernacular security is the result of socially specific speech acts that seek to establish imagined communities at the "global", "national" or "local" level'. As will be shown in the case study below, while situated in a rural community in the outback of Upper Egypt, 
men spoke about how they took to the streets in mid-July in response to what they saw as a Western conspiracy against their revolution of 30 June 2013.

A vernacular lens does not signify a binary approach to security as being either about the security of the state or that of the citizen; rather, it allows for adopting a more relational approach. Rather than focusing on the content of the security agenda per se, or the internal institutional setup, a relational approach seeks to capture how security is experienced, mediated and perceived through the daily interactions between security actors and the interpretation of the role of security in shaping overall power configurations. Jarvis and Lister suggest that scholarship of this sort contributes to significantly broadening 'our knowledge of security's social meanings and roles. It offers an opportunity, put otherwise, to offer a fuller genealogy of how and by whom security is spoken, performed and experienced away from the elites' (Jarvis and Lister 2013: 162).

Adopting a socially embedded approach to the study of security allows for an understanding of how these experiences affect the relations between citizens and each other, whether on a collective or individual basis: "how designations of (in)security are implicated in other social dynamics as identity formation (individual and collective) and the (re)production of political exclusions' (Jarvis and Lister 2013: 161-62).

Moreover, the vernacular itself is highly fluid and far from being static. An individual's vernacular understanding of security 'is contextually and historically linked to shifting ontologies of uncertainty' (Bubandt 2005: 291). This is particularly critical for understanding people's insecurities in the context of Egypt where power configurations were changing very rapidly and where narratives and imaginaries of the sources of threat were being rethought in deeply unsettling circumstances.

Luckham and Kirk (2013: 35) note the paucity of research in vernacular security studies, especially that which is informed by a research design that makes 'contextually sensitive inquiries that pick apart security's multiple meanings'. The findings shared below derive from a number of sources.

A study that was undertaken between October 2013 and January 2014 intended to adopt an agential view to (a) understand citizen perceptions of their experiences of violence prior to and after the revolutions of 2011 and 2013, the kinds of violence that affect them most, their views on which actors are responsible and their sense of what needs to be done and (b) understand why people endorsed and/or participated in the protests against President Morsi that erupted on 30 June 2013. In order to fulfil the twin objectives of the survey, a purposive sample was taken of all those who had participated in or endorsed the protests of June 2013 against the regime. In other words, only those who claimed they supported the revolution of 2013 were included in the sample. The total sample taken (excluding some incomplete questionnaires) was 2,423 . As it was a purposive sample, the aim was to try and get a balanced representation in rural/urban contexts, geographic coverage of the country, and gender. This was complemented with 12 focus groups, two in each governorate (Cairo, Alexandria, Fayoum, Beni Suef, Minya, Qena). A second source of data that informed this study consisted of four more focus groups that were held in Minya in January 2015, two with young people (one with men and one with women). There were three sites for the focus groups with Copts: one in Cairo and two in Minya. It has been observed that though Christians and Muslims do not live in segregated communities, Christians tend to be most concentrated in the large cities (Cairo and Alexandria) and Upper Egypt (in particular Minya and Asiut). The focus groups held in Cairo were held in an urban squatter settlement north of Cairo, on its outskirts, called Moassasset Al Zakat. The focus groups in Minya were held in one urban and one rural context. The urban context was that of Abou Qorqas, a town with a large Christian minority but surrounded by several villages with Muslim majority populations. The rural context was that of Al Amoudein, a majority Christian village surrounded by several villages of Muslim majority population. 
Since the focus here is on capturing the perspectives of Christian minorities in relation to vernacular securities, it is important to describe the religious composition of the groups and how the participants were selected. In Alexandria, Fayoum, Beni Suef and Qena, the focus groups tended to be predominantly Muslim. In Cairo and Minya all the focus groups were Christian with the exception of one focus group that was mixed (and features prominently in the findings of the research below). There were two overall factors that influenced participant choice. The first is diversity across age, gender, religion, and rural/urban differentials for the focus groups as a whole across the overall sample. The second key factor was the positionality of the researcher in the focus group, i.e. how her/his identity is perceived in the community and the extent to which the community responds to it through trust and ease of communication. For example, focus groups with Christians were facilitated by researchers who were Christians and from within the community. Moreover, focus groups with men tended (with the exception of a couple) to be facilitated by researchers who were from within the community. In view of the sensitivity of the questions and the deep polarisations in the communities (along both political and religious lines) it was critical that the facilitators be regarded by the participants as trustworthy people since otherwise the content would be artificial and contrived. The analysis presented in this paper is primarily based on focus groups with Copts. There are some limited comparisons with all-Muslim focus groups in order to capture some of the broader contextual dynamics that are relevant to the population at large. As the majority of Copts do not live in enclosed segregated communities but are embedded in communities in which their everyday experiences involve interactions with Muslims, it was deemed enriching to capture both the narratives about Muslims and dialogue with them. There is a striking difference certainly between the two; however, one of the focus groups that was mixed, comprising both Muslim and Coptic women, is also presented in Section 3.9, the aim being to shed light on the mediation of insecurities in relation to the religious 'other'.

In line with Bubandt's social constructivist approach, the emerging findings were discussed with both the facilitators through frequent consultations and joint reflections. The survey was useful both for triangulation and corroboration of evidence. As the survey study complemented the focus groups, it allowed for a validation of the findings and an indication of how widely prevalent/representative a phenomenon is.

One of the challenges faced in synthesising these findings is the amount of careful distillation required. One had to differentiate between what is personal experiential, what is based on rumours heard from others (whose authenticity is questionable but whose circulation is indeed important for people's cognitive outlook) and what is based on what has been heard in the media (in a context in which the media acquired considerable influence on political culture).

\section{Multiple experiences and framings of security in the vernacular}

While vernacular understandings of security and insecurity are fluid, there is still a need to find appropriate ways to present them in a way that speaks to the pluralism of perceptions and experience, and that aspire to be 'speaking with' rather than 'on their behalf'. Jarvis and Lister provide a very useful typology comprised of meanings of security, key features, internal variances and examples as a way of presenting the vernacular securities of various groups in the UK. I have expanded on this excellent typology to allow for the interface of security/insecurity in definitions, and have also added perceived 'function' of the type of security/insecurity identified, the actors and relationships involved, and how these changed from the perspective of the citizens who took part in the focus groups. In the vernacular, people used two words interchangeably with reference to security: amn and amaan. Amn is 
usually used to mean security; however, sometimes it can also be used to mean safety. Amaan is also used to mean safety, and is far broader in its potential meanings than security. It cannot be emphasised enough that the content presented in this typology represents the perspectives of the Coptic individuals within focus groups, and that a typology representing the perspectives of other groups would in many instances look dramatically different. Moreover, it is also important to note that the table below summarises the perspectives of citizens in both rural and urban contexts, though there are variations.

\subsection{Insecurity as vulnerability to state-bolstered retribution}

In almost all focus groups, across ages, genders, geographic location and socioeconomic backgrounds, one of the greatest sources of insecurity (adam amaan) that participants talked about was how they were made to pay the price as members of a religious minority for having voted against Morsi in the presidential elections. It was no secret that the overwhelming majority of Copts had voted against President Morsi. No matter what measures and discourses were used to allay their fears that an Islamist-led state would circumvent the rights of Copts, this seemed to have no impact on their voting patterns. If the choice is between an Islamist and a non-Islamist candidate, there was a pattern of consistently choosing the latter.

Following Morsi's assumption of the presidency, Copts in the focus groups said Muslims, out of the blue, would pop the question rhetorically: 'Why do you hate Morsi? Why did you not want him as president?' The question was not intended to inquire why Morsi was not acceptable politically, but why Copts reject Islamist rule and whether their rejection of those who wish to establish an Islamic state is a rejection of Islam itself. Both sides knew exactly what was meant between the words in these vernacular conversations, the hidden subtexts behind them. Most of the Copts in the focus groups would go quiet but those who did reply emphatically denied any hatred of Morsi.

N., a middle-aged Coptic woman (Cairo focus group, December 2013), said how being visibly a Copt (by not being veiled) led to her exposure to many conversations and incidents in which strangers, out of the blue would ask her why the Copts hated Morsi (as if she was a spokesperson for the 10 million citizens). She explained that this became a source of extreme insecurity in her daily interactions in public. After Morsi was ousted, this sense of being the subject of revenge by just about anyone who voted for the Muslim Brotherhood candidate entirely disappeared:

When I used to take a taxi he (the driver) used to ask me 'did you vote for Shafik or Morsi?' The driver would say 'Morsi is your lord, he will chastise/punish you' and I felt unsafe and thought my staying in the house is better [than going out] but now I take a taxi and none of this happens. I no longer feel alienated in my own country.

The word commonly used in vernacular language that featured frequently in the focus groups was hayrabeekoh, meaning discipline and punish you (in the plural). While some of it was experiential, such as what $\mathrm{N}$. referred to above, the sense of forthcoming revenge was also ignited by the circulation of rumours about what would happen once the Muslim Brotherhood was fully in charge - gayelko el hayrabekoh (the idea of this strongman who would put the Christians in their place) - but which was sometimes expressed in the streets in terms of 'we', as in what 'we will show you'.

Participants in the focus groups talked about the random exertion of a relationship of power over them by anyone who sympathised with the Islamists, not only in government, nor only by members of the Muslim Brotherhood, but also in ordinary citizen relations. The words commonly used were este'waa, which derives from the word power (qowah), which in its vernacular use means the exertion of a power over (namely, power over for the purpose of subjugating, presiding over someone). 
Table 3.1 Typology of vernacular Coptic securities/insecurities

\begin{tabular}{|c|c|c|c|c|c|c|c|c|}
\hline & $\begin{array}{l}\text { How security/insecurity } \\
\text { is understood }\end{array}$ & Internal variances & Its features & Its function & $\begin{array}{l}\text { Actors/relationships } \\
\text { involved }\end{array}$ & Examples & $\begin{array}{l}\text { Impact/insecurity } \\
\text { outcome }\end{array}$ & $\begin{array}{l}\text { Change following } \\
\text { regime overthrow }\end{array}$ \\
\hline 1. & $\begin{array}{l}\text { Insecurity as vulnerability } \\
\text { to state-sponsored } \\
\text { revenge, retribution }\end{array}$ & Very little & $\begin{array}{l}\text { Everyday threats, } \\
\text { rumours, practices } \\
\text { estekwa'a }\end{array}$ & \begin{tabular}{|l} 
Revenge for \\
resisting Morsi, put \\
them in their place
\end{tabular} & \begin{tabular}{|l|} 
Islamist movements, \\
members and those \\
ordinary citizens who \\
support them (not only \\
the Muslim \\
Brotherhood)
\end{tabular} & $\begin{array}{l}\text { Morsi hayrabeeko } \\
\text { Morsi seedko }\end{array}$ & $\begin{array}{l}\text { Sense of identity at } \\
\text { risk }\end{array}$ & $\begin{array}{l}\text { With Morsi out of power, } \\
\text { while new threats of } \\
\text { revenge, but not state- } \\
\text { empowered, sense of no } \\
\text { more encroachment on } \\
\text { identity }\end{array}$ \\
\hline 2. & $\begin{array}{l}\text { Insecurity on account of } \\
\text { religion-mediated } \\
\text { citizenship }\end{array}$ & \begin{tabular}{|l|} 
Majority Christian \\
village felt it less \\
than other contexts \\
where they are a \\
minority
\end{tabular} & \begin{tabular}{|l|} 
(both identity and \\
rights and privileges) \\
Discourses and \\
practices of us and \\
them. Country divided \\
into maseheyeen we \\
moslemeen
\end{tabular} & $\begin{array}{l}\text { Create unity and } \\
\text { pride among the } \\
\text { Muslims of being an } \\
\text { Ummah, force } \\
\text { Christians to } \\
\text { subordinate }\end{array}$ & \begin{tabular}{|l|} 
Islamist preachers, \\
media, educational \\
system, everyday \\
citizens, those in \\
government \\
institutions (civil \\
service) on all levels \\
\end{tabular} & \begin{tabular}{|l|} 
Educational \\
segregation in the \\
classrooms at all \\
levels. Voluntary \\
segregation of farmers \\
when in the fields on \\
the basis of religion \\
\end{tabular} & $\begin{array}{l}\text { Removal of children } \\
\text { from school }\end{array}$ & $\begin{array}{l}\text { Segregation along } \\
\text { religious lines in classes } \\
\text { reversed, pressure on } \\
\text { female students to cover } \\
\text { hair eased, day labourers } \\
\text { back to eating together }\end{array}$ \\
\hline 3. & $\begin{array}{l}\text { Amaan from taking on the } \\
\text { symbol of being the } \\
\text { subject of an Islamist } \\
\text { state/fear of assimilation }\end{array}$ & \begin{tabular}{|l|} 
Gender differential \\
acute, Coptic \\
women feeling it \\
more than men, \\
young women \\
especially defiant
\end{tabular} & $\begin{array}{l}\text { Threats and rumours } \\
\text { of what will happen to } \\
\text { those who don't 'cover } \\
\text { up' }\end{array}$ & $\begin{array}{l}\text { To cover up - have } \\
\text { a Christian } \\
\text { equivalent to the } \\
\text { Muslim veil as a sign } \\
\text { of modesty and } \\
\text { subservience to the } \\
\text { new system }\end{array}$ & \begin{tabular}{|l|} 
slamist women and \\
men in state \\
institutions and \\
informal leaders in the \\
community
\end{tabular} & \begin{tabular}{|l|} 
Girls being asked to \\
don the headscarf at \\
school, in some \\
contexts women \\
willingly wearing \\
headscarf to avoid \\
problems
\end{tabular} & $\begin{array}{l}\text { Sense of identity under } \\
\text { extreme threat, cases } \\
\text { of compliance but } \\
\text { many cases of } \\
\text { resistance. } \\
\text { Fear of having to stay } \\
\text { at home }\end{array}$ & $\begin{array}{l}\text { No more pressure on } \\
\text { women interviewed to don } \\
\text { any kind of head covering } \\
\text { whether from } \\
\text { husbands/brothers/fathers } \\
\text { or in state institutions. } \\
\text { Women no longer worry } \\
\text { about having to be forced } \\
\text { back home }\end{array}$ \\
\hline 4. & Amn as bodily integrity & \begin{tabular}{|l|} 
Urban women \\
complained more \\
than rural \\
counterparts, men \\
sensing it much \\
less
\end{tabular} & $\begin{array}{l}\text { Men harass women on } \\
\text { scale and intensity } \\
\text { even worse than } \\
\text { during Mubarak reign }\end{array}$ & $\begin{array}{l}\text { Exercise of power } \\
\text { over, intimidation }\end{array}$ & $\begin{array}{l}\text { Men of all ages as } \\
\text { individuals and in } \\
\text { groups }\end{array}$ & Sexual harassment & $\begin{array}{l}\text { Women fear going out, } \\
\text { restrict mobility and } \\
\text { seek chaperone }\end{array}$ & $\begin{array}{l}\text { Sexual harassment } \\
\text { continues }\end{array}$ \\
\hline 5. & $\begin{array}{l}\text { Amn as susceptibility to } \\
\text { individual and organised } \\
\text { thuggery }\end{array}$ & $\begin{array}{l}\text { Major threat } \\
\text { identified by all }\end{array}$ & $\begin{array}{l}\text { Wide prevalence of } \\
\text { baltageya }\end{array}$ & $\begin{array}{l}\text { Highly controversial, } \\
\text { why the police } \\
\text { retreated - revenge }\end{array}$ & $\begin{array}{l}\text { Baltageya take over, } \\
\text { state of lawlessness, } \\
\text { organised criminal } \\
\text { activities }\end{array}$ & \begin{tabular}{|l|} 
Generic fear of \\
violence for Copts, in \\
particular fear of \\
ransom payments and \\
kidnappings
\end{tabular} & $\begin{array}{l}\text { Reduced mobility, shift } \\
\text { to more expensive } \\
\text { transport methods }\end{array}$ & $\begin{array}{l}\text { Fear persists, but more } \\
\text { contained }\end{array}$ \\
\hline 6. & $\begin{array}{l}\text { Amn as threat of loss of } \\
\text { haybet al dawla. State } \\
\text { integrity/sovereignty }\end{array}$ & All & Absence of rule of law & $\begin{array}{l}\text { Transfer to } \\
\text { community policing }\end{array}$ & $\begin{array}{l}\text { Informal power to } \\
\text { Islamist groups }\end{array}$ & $\begin{array}{l}\text { Fearing the police } \\
\text { officers, suspecting } \\
\text { their allegiance to the } \\
\text { movement }\end{array}$ & $\begin{array}{l}\text { Reliance on self- } \\
\text { protection methods } \\
\text { and adoption of } \\
\text { minimising public } \\
\text { interactions }\end{array}$ & $\begin{array}{l}\text { Support for strong state } \\
\text { back, suspicion of police } \\
\text { complicity slightly } \\
\text { reduced. } \\
\text { However, fear of security } \\
\text { turning against the church } \\
\text { is also present }\end{array}$ \\
\hline
\end{tabular}




\section{Table 3.1 (cont'd.)}

\begin{tabular}{|c|c|c|c|c|c|c|c|c|}
\hline & $\begin{array}{l}\text { How security/insecurity } \\
\text { is understood }\end{array}$ & Internal variances & Its features & Its function & $\begin{array}{l}\text { Actors/relationships } \\
\text { involved }\end{array}$ & Examples & $\begin{array}{l}\text { Impact/insecurity } \\
\text { outcome }\end{array}$ & $\begin{array}{l}\text { Change following } \\
\text { regime overthrow }\end{array}$ \\
\hline 7. & $\begin{array}{l}\text { Amn as national security } \\
\text { from terrorist threat }\end{array}$ & $\begin{array}{l}\text { Reported } \\
\text { especially by men }\end{array}$ & \begin{tabular}{|l|} 
Perceived threat from \\
Islamist groups after \\
the overthrow of Morsi, \\
in particular from Sinai
\end{tabular} & $\begin{array}{l}\text { To restore Islamist } \\
\text { rule }\end{array}$ & $\begin{array}{l}\text { Pro-Morsi faction who } \\
\text { are resorting to } \\
\text { violence targeting } \\
\text { soldiers and } \\
\text { Christians, believed to } \\
\text { be supported by } \\
\text { Western powers }\end{array}$ & Burning of churches & $\begin{array}{l}\text { Avoidance in some } \\
\text { instances of collective } \\
\text { protests of visible } \\
\text { displays of support for } \\
\text { Al-Sissi }\end{array}$ & $\begin{array}{l}\text { Sense of sacrifice for } \\
\text { Egypt, increased hatred } \\
\text { towards the Islamists and } \\
\text { support for increased role } \\
\text { of the state in surveillance, } \\
\text { patrol and guarding of } \\
\text { churches. } \\
\text { Tawfeed strong } \\
\text { endorsement of Al-Sissi }\end{array}$ \\
\hline 8. & $\begin{array}{l}\text { Insecurity as fear for the } \\
\text { future - not only the } \\
\text { present }\end{array}$ & $\begin{array}{l}\text { This was very } \\
\text { gendered, with } \\
\text { women fearing for } \\
\text { their sons and } \\
\text { sons fearing for } \\
\text { their futures more } \\
\text { than for daughters }\end{array}$ & \begin{tabular}{|l|} 
Perceived political will \\
to significantly \\
marginalise Christians \\
across generations
\end{tabular} & Privilege to Muslims & $\begin{array}{l}\text { Muslim Brotherhood's } \\
\text { rule seen as indefinite }\end{array}$ & $\begin{array}{l}\text { Copts' own panic and } \\
\text { hysteria about the } \\
\text { youth's future being } \\
\text { lost }\end{array}$ & $\begin{array}{l}\text { Desire to leave the } \\
\text { country, sense of } \\
\text { despair }\end{array}$ & $\begin{array}{l}\text { Cautious absence of } \\
\text { pessimism, rather than } \\
\text { strong optimism }\end{array}$ \\
\hline 9. & $\begin{array}{l}\text { Amaan/amn as absence of } \\
\text { peaceful and harmonious } \\
\text { coexistence with the } \\
\text { religious other }\end{array}$ & $\begin{array}{l}\text { Particularly felt } \\
\text { where they are a } \\
\text { numerical minority, } \\
\text { more so reported } \\
\text { by the middle-aged }\end{array}$ & $\begin{array}{l}\text { Suspicion of } \\
\text { neighbours and } \\
\text { friends, fear of } \\
\text { interacting with them }\end{array}$ & $\begin{array}{l}\text { Ghettoisation of the } \\
\text { Christian community }\end{array}$ & \begin{tabular}{|l|} 
Ordinary citizens and \\
Islamist leaders who \\
use the mosque \\
pulpits to plant \\
suspicion of Christians
\end{tabular} & $\begin{array}{l}\text { Neighbours no longer } \\
\text { talk to each other, } \\
\text { suspected ill faith on } \\
\text { the part of each other }\end{array}$ & $\begin{array}{l}\text { Minimal engagement, } \\
\text { refraining from } \\
\text { interactions }\end{array}$ & $\begin{array}{l}\text { Dramatic improvement in } \\
\text { relations among friends } \\
\text { and neighbours though } \\
\text { tensions continue to } \\
\text { simmer under the surface }\end{array}$ \\
\hline
\end{tabular}


The ousting of Morsi did not necessarily mean that those who belonged to the Islamists did not see the Copts as deserving of revenge. On the contrary, the incidents of violent revenge by pro-Morsi factions increased dramatically, both in scale and intensity (see below). Copts were seen as the bulk of the citizens who had revolted against Morsi and therefore even more deserving of revenge. However, the difference in many Copts' rationalisation of this is that this revenge was not rolled out in the name of the state or invoking the power of the state. For many Copts, the overthrow of Morsi meant that the hanging sword of being associated with the Christians who do not want Islamist rule was no longer in place, for two reasons. First, although the revenge was intense and systematic, at least it was not backed by the state (or this is how it was interpreted). Second, there was now a new polarisation that was political not religious: Muslims and Christians favoured the revolution while the pro-Morsi supporters (Muslims) rejected it. The lines of demarcation were no longer drawn on assumed ideological lines but on political ones.

Hence, it was not so much that measures were taken to reject treating Copts as traitors to Islam (by rejecting Islamist rule) but that one of the unintended outcomes of the overthrow of Morsi was that those who wanted to put Copts in their place could no longer do so by invoking the power of an Islamist leader residing over an Islamist state.

The increased surveillance over mosques again had the unintended consequence of making any hate speech made from the mosque pulpits less public. Conventionally, the Friday prayers and sermons are broadcast through speakers attached to the outside of the mosque so that people outside could hear, thus extending a significant outreach into the nearby streets. The generation of hate speeches through mosques against Christians is not a generalisable phenomenon, and is contingent upon leadership, political moment, and a multitude of factors. Focus group participants said that with the new surveillance of the discourses of the mosques and regulation of their speech, the speakers would go off around certain subjects, including that of Christians!

Table 3.2 What factor do you think most accounts for the increase in violence since $2011(\%)$ ?

\begin{tabular}{|l|l|l|l|}
\hline Factors & Muslim & Christian & Total \\
\hline Thugs & 59.8 & 40.6 & 54.5 \\
\hline Security & 18.8 & 14.6 & 17.5 \\
\hline Extremist groups & 19.2 & 40.6 & 25.3 \\
\hline All of the above & 0.3 & 3.5 & 1.2 \\
\hline Other & 0.2 & 0.3 & 0.2 \\
\hline Do not answer & 01.7 & 0.5 & 1.4 \\
\hline Total & 100.0 & 100.0 & 100.0 \\
\hline
\end{tabular}

If Copts saw revenge as a main driver of insecurity during Morsi's tenure, then it would seem paradoxical, almost inconsistent, that they would then talk about an abatement of animosity after his overthrow when they were exposed to the most intense backlash from the pro-Morsi camp that they had ever witnessed in such a short period of time. Shortly after the overthrow of President Morsi, a string of attacks on churches began. On 3 July, Abdel Fattah Al-Sissi, Minister of Defence, announced a roadmap that effectively terminated Morsi's tenure and made Adly Mansour, the head of the Supreme Constitutional Court, interim president. This was broadcast on national television, and was backed by the participants who had convened with Al-Sissi. These included Sheikh Ahmed el Tayeb, heading Sunni Islam's most respected establishment body, Al Azhar, Pope Tawadrous, leader of the Coptic Orthodox Church, representing followers of the Coptic faith, Mohamed Abd el Azziz, a representative of Tamarod, the youth movement that called for the 30 June uprising, Mohamed el Baradei, representing the non-Islamist political parties, and Galal el Morah, the secretary general of the Nour party, the political wing of the ultra-radical Islamists. 
What followed was a series of attacks on places of Christian worship, property and individuals throughout July and into August (see for example, Hanna 2013, Waheeb 2013). Human Rights Watch announced that several attacks on Christians had taken place in governorates across Egypt, including Luxor, Marsa Matrouh, Minya, North Sinai, Port Said, and Qena, during a period of less than three weeks after Morsi was ousted (Human Rights Watch 2013). In many of the incidents, witnesses told Human Rights Watch that security forces failed to take the necessary action to prevent or stop the violence.

The greater the intensity of the security crackdown on the Muslim Brotherhood, the more ferocious the pro-Morsi backlash against the Copts became. On 14 August 2013 the proMorsi protests at Rab'a and AI Nahda Squares in Cairo were cleared using excessive force by security personnel, leading to the death of many protestors as well as several police officers. Further, there were large-scale attacks involving looting and torching of Copticowned private and commercial property and several murder incidents.

Professor Tareq Ramadan, grandson of Hassan el Banna, the founder of the Muslim Brotherhood, questioned whether the Muslim Brotherhood were behind the attacks on the Copts, suggesting it may have been the work of the security intelligence (BBC 2013). However, since these attacks were often committed in daylight, it was possible to see the identity of the perpetrators. Members who were known in the community to be followers of the Muslim Brotherhood were seen to be attacking churches. Also, the writing on the walls of many churches was further evidence of the identity of the perpetrators, with slogans such as 'Tawadrous the Sissi's dog' and Islamiyya Islammiyya inscribed on their walls. Further, prior to the overthrow of Al-Sissi, the Muslim Brotherhood media outlets openly broadcast messages that the Copts would suffer the consequences of any participation in the uprisings.

Nonetheless, while the perpetrators were from the pro-Morsi faction, undoubtedly the scale of assault on places of worship was testament to the failure of the government to provide the most minimal security and the adoption of an almost laissez faire attitude towards the systematic targeting of places of worship nationwide.

In many incidents in the summer of 2013 where the churches were not burnt, it was because Muslims stepped in and formed cordons, refusing to let this happen to the parish churches frequented by their neighbours, friends and co-workers. In the village of Al Amoudein, men in the focus groups described how when many members of the leading Muslim families heard about the burning of the churches in other parts of the governorate, they congregated in front of the church, armed, and said they would ward off any attacks on it. This act of solidarity is remembered with extreme fondness by the Christians in the village, in particular since these families were courageous enough to circulate threats that they would immediately shoot anyone who attempted to attack the church, not caring if they were Muslim. It is ironic that it was community policing that took on the security role, rather than the formal state institutions.

Surprisingly, unlike other incidents in which Copts were very vocal in condemning security negligence for failure to protect churches against attacks, the narratives of many Copts captured in focus groups hardly mentioned security laxity and spoke about the intensity of the vengeance of the pro-Morsi faction against them. This was narrated in both religious and patriotic language. The language used to describe the torching of their places of worship was one full of references to 'sacrificial giving', to 'the cross that we must carry', to the 'history of a persecuted church not shying away from giving'. In patriotic terms, people spoke of the price they are willing to pay to 'save Egypt from the Brothers' and to 'restore Egypt to Egyptians'. The language bordered almost on a patriotic struggle against foreign occupation.

Consequently, the paradox of Copts' conception of the vengeance being more threatening to them during Morsi's era than what followed emanates from the belief that the former was emboldened by an Islamist government, while the latter occurred as a price for the rejection 
of Islamist rule. For the Copts, whether the violence was experienced during Morsi's tenure or out of it, it was perpetrated by the same actors: the Islamists. It is only by engaging with the vernacular narratives of the Coptic citizenry that one is able to disentangle why increased violence did not translate into increased insecurity. What it has done, however, for many Copts is deepen animosity towards the Muslim Brotherhood and made them less willing to see coexistence as possible (see below on reconciliation).

\subsection{Safety from obtrusive aspects of unequal citizenship}

While sectarian sentiment had been growing during Mubarak's reign, with social cohesion between Christians and Muslims in many communities under strain, what many women and men in focus groups reported was that relations became particularly strained in the aftermath of the 25 January revolution and especially so after President Morsi won the elections. This needs to be understood in a context of the country already being deeply polarised between Islamists and non-Islamists. When one middle-aged woman (Cairo, December 2013) talked about the insecurity emanating from the country being split into two groups, Christians and Muslims, another participant interjected: 'but even the Muslims they (the Islamists) would split into those that are with them and those that are not'. However, for Christians this political polarisation was translated into patterns of religious discrimination that became more overt and intense.

One of the sites of these extreme forms of religiously mediated experiences of citizenship was in the educational arena. The most dramatic changes reported were in the practice of segregated classes along the lines of religious identity. In the urban community in which this research was undertaken parents pointed out that while not happening in the entire school, some teachers decided to switch the students around in certain forms so that there would be an all-Muslim class or an all-Christian class. This segregation along religious lines was initiated by individual teachers and did not emanate from an educational policy at any level. They also reported that while individual children had occasionally suffered from incidents of religious discrimination by particular teachers rather than as a collective treatment, this changed. Christian students would be completely ignored; for example whenever they raised their hands, they would be treated as non-existent and would be spoken to with exceptional roughness (bearing in mind that schoolchildren in Egypt generally suffer from a great deal of abusive behaviour).

Individual teachers also began to pick on Christian girls, scold those who were wearing trousers and insist that some did not come into school without wearing an escharpe, a headscarf. One parent said she was so outraged that she went to the school and told the teacher that she does not want her daughter to wear a headscarf. In other instances, parents said that religious education classes for Christians were simply dropped so they would sit outside until their Muslim counterparts finished their classes.

It is not only in the classrooms, but in the playgrounds, in the after-school classes, outside the gates, that Christians have felt encroached upon. One of the common recurring themes across poor urban and rural contexts is that of targeting Christian children outside school gates. From the focus groups with women and men in Al Amoudein, parents complained of a pattern of groups using hate speech and beating up Christian children upon their arrival at or departure from school. One of the mothers in Al Amoudein described in the vernacular this level of vulnerability to violence as 'persecution': 'There are these children who wait for the Christian students to turn up at the school gates and would beat them up. There is great persecution in front of the schools'. During 2012/2013 participants in the focus groups said that some parents withdrew their children from school and opted for distant education in order to avoid the incidents of violence in the schools in nearby towns (they do not have secondary schools in the village). 
It is interesting that education became the site for discriminatory practices not only for schoolchildren but also for adults. In Egypt, adults can apply to take literacy examinations to certify that they are literate. These exams are held in local venues and are administered by local staff on a regular basis. Women in the focus group (Cairo, urban) said that in 2012, all the Christians were rounded up in one class to undergo the exam, which seemed odd because previously the classes were mixed.

This hierarchical segregation of citizens on a religious basis was also experienced in other public spaces and spheres.

Street interactions had already changed in many communities and quarters because of the increasing powers of the baltageya (thugs - see below) who terrorised just about everyone. However, religious discrimination became a defining character of many of the day-to-day interactions that women and men said had not existed before. The most commonly cited examples were:

- $\quad$ changes in relations in the market: some openly calling upon Muslims not to buy products from Christian sellers, Christian buyers saying that some sellers treat them badly. In response Christians would hire transport so that they could purchase their needs from other markets (urban Cairo context);

- $\quad$ government establishments: instances where they were served last even though they were ahead in the queue, or faced exceptional difficulties in having their paperwork processed (more than the usual) (rural context, Minya);

- transport: in incidents where drivers did not welcome Christian children on board their $\mathrm{micro} / \mathrm{minibuses}$, their parents would hire a driver with a vehicle as alternative transport (rural context, Minya).

In urban Cairo a common complaint was that the local bakery that sells subsidised bread would serve Muslims first, and make Christians queue. If a Muslim came by, s/he would be given precedence over all the Christians waiting. Fear of being held accountable would lead the baker not to sell any bread to the Christians at all. In one instance, Christians went en masse to another bakery where they would be better treated, even though it was further away for many.

One of the most important aspects of these practices is that they did not emanate from any discriminatory government laws or decrees. They emanated froim individuals affiliated (or not) to formal and informal Islamist movements taking the initiative of creating hierarchies among citizens on religious grounds. This was occurring in a state of general lawlessness with minimal formal or informal mechanisms of accountability.

In Al Amoudein village, one participant said that a series of Muslim neighbours decided to build a door on the narrow street, effectively blocking anyone who passed along it - even though it was a public street.

The particular sites of discrimination given above are the ones that focus group participants said had changed after the downfall of the Morsi regime.

- $\quad$ Classes were reintegrated once more in the school in question in urban Cairo;

- $\quad$ Girls were no longer asked by their teachers to cover their hair;

- $\quad$ Religious education classes for Christians were reinstated;

- Market relations improved by and large, though individual incidents of discrimination continued;

- $\quad$ In Al Amoudein, while the door was not removed from the passageway, Christians were allowed to freely pass through it;

- $\quad$ The local bakery in the urban Cairo quarter reverted to serving on a first-come-firstserved basis; 
- The most acute forms of discriminatory behaviour in the government offices in question were no longer experienced

This does not by any stretch of the imagination suggest the presence or exercise of citizenship unmediated by religious discrimination. Certainly, the deeply entrenched prejudices continued to influence daily life. However, the above are concrete indicators of sites of attenuated discrimination that had subsided, from the point of view of participants in the focus groups. It may be that all of these forms of religious discrimination are being experienced in other contexts by other Copts - hence without a nationwide survey, it is impossible to arrive at definitive conclusions; however, they are highly illuminating about what informs their perceptions and how they conceive of their experiences.

What explains the changes in these practices? Participants were very clear that the changes did not necessarily indicate a genuine change in relations between Christians and Muslims in terms of diminished mistrust and insecurity where it already existed. However, they attributed the change to a kind of meltdown. Those who felt empowered to differentiate along religious lines were no longer emboldened by a government that prides itself on being Islamic. In other words, the new configurations of power on the macro level were completely reversed after 30 June 2013 such that the Islamists became a political minority, demonised and ostracised by both state media and large parts of the population. From the perspective of the focus group participants, this change of government disempowered those who openly discriminated against them because they could not count on community silence about these practices and on the silence of the Copts themselves. Copts began to respond to overt forms of discrimination, in vernacular terms, 'with an emboldened heart' (be'alb gamed) more so than before.

\subsection{Insecurity emanating from non-conformity as a non-veiled Christian woman}

In the context of the working and middle classes the great majority of Muslim women are veiled and Coptic women stand out on account of their bare head. This was a source of contention during Mubarak's era as well, however, the overt forms of encroachment became more pervasive and acute from 2011 onwards. The Muslim Brotherhood who came to power did not issue any law requiring women to veil, nor did they officially propose it. However, on a local level, the experience of Coptic women was one of intense insecurity on account of how their gender and religious minority status intersected to generate new vulnerabilities.

Individuals' accounts indicated regular exposure to suggestions to 'cover their hair' or 'wear an escharpe' on the street, in transport, in places of work, in educational institutions.

Sometimes there was nothing said, but it was how they were made to feel in terms of the gazes they received.

A number of words were used to describe this sense of anxiety/insecurity. A woman from the Cairo focus group said in 2013 that when she used to take the subway to go to her literacy classes with her friend, and when both of them would be visibly the only two Christians in the carriage, she would feel that others raised their voices in reading the Koran and would intimidate them. 'I felt alienated in the country, really despised (manbouza)'.

While no official decree was taken about women complying with any kind of dress code, the role of rumours generated a great deal of insecurity. There were rumours that women would enter a carriage unveiled, and leave it covered after having been forcibly veiled. Rumours played an integral role in sustaining the anxiety that women would be forcibly made to take on this symbol of compliance with Islamic codes of behaviour.

In some instances, women confided that members of their family began to propose that when out in public they should cover their hair in order to avoid trouble. One middle-aged urban woman from Cairo shared the following anecdote: 'I was in el balad (a term in this context 
referring to her going back to the countryside where her family originated) and my son got sick, my brother in law told me "put on a gallabiyya [loose full length cover] and a scarf on your head before you leave"'.

$\mathrm{S}$, whose husband is a teacher at a local school, said that the security scare led to her husband pressing her to put a scarf on her head when she was out. It is significant that these women were not donning any conventional form of veiling but were wearing a headscarf that still distinguished them as Christians. Many expected that it was only a matter of time before they would be forced to wear a head covering, which would drive many to choose to stay at home.

While the resistance was to the veil as a symbol of being Muslim, many of the women talked about the implications not only in terms of a threat to their identity but to their way of life, suggesting that those who chose not to conform may have been left with little choice but to stay at home to avoid trouble. Hence it was the threat to mobility and public interaction that they felt would be the price they would eventually have to pay.

Following the overthrow of Morsi, Coptic women's experiences on the streets were certainly not transformed into safe and secure ones. As will be shown below, the threats to their bodily integrity in public spaces continued. However, what these women reported was that they no longer felt that covering their hair was needed nor imminent. Family members no longer suggested they put on a scarf, and the individuals who dared tell them they should cover up went quiet. Moreover, the rumours, about how under the Islamists all women would be forced to don the veil sooner or later, evaporated.

\subsection{Feeling safe to walk the streets free from sexual harassment}

While Coptic women suffered from religion-specific forms of pressure to cover up, all Egyptian women suffered from the increase in sexual assault that was manifest in both its intensity and its prevalence. This was a common complaint across women of all ages, geographic location and socioeconomic position. This was attributed in the vernacular to the lack of morals, the absence of police and the lack of intervention on the part of passers-by and observers to take action when offences were happening in front of them (for full description of their experiences see Tadros 2012).

However, though the police partly returned to the streets of Egypt in 2013, women, across the board, continued to experience the most horrendous forms of sexual harassment. The community is still not intervening and the police continue to be ineffective (in fact they are accused of being implicated in acts of sexual harassment themselves). This substantive form of insecurity is deeply gendered and shows a sharp contrast in the experiences of Coptic men (of all ages in rural and urban contexts) compared to the experiences of Coptic women. Coptic men interviewed in October 2013 and January 2015 were keener to point out how their experience of insecurity has been largely improved on account of the increased presence of the police force. When asked about women's exposure to sexual harassment, they almost unanimously argued that women are now exposed to less of it on account of the return of the police. This was in stark contrast with the focus groups with women where their assessment of security was less positive, the reason being their continued vulnerability to sexual harassment in transport, on the streets and in the markets. Unlike men who reported they may go to the police station if need be, the women's replies were, irrespective of age and geographic location, in the negative. 'No we can't. You know how they would harass girls, so they can't be trusted'.

This is critical for showing how gender affects one's perception of one's own insecurity and overall assessment of the security situation in the country, and also how it makes one oblivious at times to the experiences of the other gender (e.g. Coptic men not recognising Coptic women's continued insecurity on account of harassment). Sexual harassment is also 
a feature of feeling and experiencing insecurity that Coptic and Muslim women share in common and which makes their experience distinctive from that of men of both religious affiliation.

\subsection{Insecurity as susceptibility to individual and organised acts of thuggery (baltagah)}

There have been many terms used to describe the absence of law and order or of a state to govern. The words used may be akin in meaning to fragility. They are al dawla mekhala'a the state is disjointed like a broken piece of furniture, and al balad mesh mamsoukah - the country is not 'held together', it is in disintegration.

The most common source of violence and therefore a major source of insecurity for both Christians and Muslims since 2011 in particular has been the unrestrained and increasingly oppressive role of individual and organised thugs (baltagah). The increase in baltageyah activity is a highly complex phenomenon, one obvious link being to the lax security and the almost complete absence of the police in maintaining law and order after people rose against the thugs in 2011.

Interestingly, all the women in the focus groups talked about being subjected to a particular kind of economically motivated religious discrimination. While many Christians and Muslims had to pay protection money to thugs, especially if they or their families were in vulnerable positions, Christians felt they were in some instances targeted as a religious group. While the overall percentage of Muslims and Christians who reported paying protection to avert exposure to violence was small (1.3 per cent of the total sample), if disaggregated along religious lines, there is a striking difference in responses. Among Muslims, 0.9 per cent said they paid protection to avoid being attacked, whereas 2.3 per cent of Christians said they did.

Often in urban areas, protection took the form of paying a sum of money to be left to work without having property or assets attacked or taken. In rural areas, it sometimes took the form of payment of sums in order not to have one's land occupied. When one person said in the focus group they imposed the jizya, ${ }^{2}$ another said 'it is atawa [protection money] because jizya is what a state imposes'. What is important here is the word jizya is deeply associated with the age of dhimmitude when Christians were allowed to live and work in return for paying a poll tax to the rulers. This vernacular reference to protection money as a jizya is highly indicative of the Christian fear that they may return to the state of dhimmitude, under Islamic rule.

After 30 June 2013, as the police gradually returned to maintaining law and order (if only partially), there was some reduction in the threat of thuggery.

People's perceptions were that the physical presence of the police force on the streets once more (even if they were not particularly active) had a restraining impact on the thugs. While they did not cease their activities, they became more restrained, less 'in your face' in their assaults and there were fewer incidents of kidnapping and violence. The second positive effect on thuggery came from a systematic police campaign to clear public and private spaces of weaponry.

People in the focus groups had an impression of greater security because they thought that post-2013 passers-by were more willing than previously-to intervene to help victims of assault. One middle-aged Christian woman recalled that in 2012, her son was attacked by armed men who took his mobile phone and his money. Nobody came to his rescue. Now, she thinks that if it happened again, and he called for help, people would come to help him.

Jizya is a special levy formerly imposed on People of the Book (Christians and Jews) living in Muslim majority populations under Islamic governance. 
She has no proof of that, it is purely conjecture, but it is indicative of a reduced sense of insecurity with respect to thuggery.

However, it is clearly evident that with the containment of the activities of thugs, Christians are, like Muslims, less exposed to what both had identified as a major source of insecurity. Also, for Christians, there is the unintended added advantage of feeling less vulnerable to religiously mediated acts of thuggery and protection payments.

\subsection{Insecurity as a consequence of lawlessness: Loss of haybat al dawla}

The expressed yearning for strong governance runs the risk of creating another police state, especially in view of the strong desire among many for the political clearing of the Muslim Brotherhood.

In urban focus groups, whether in Cairo or in Minya, there were no gender differentials in the emphasis placed on a new kind of security apparatus that would neither be as oppressive as that of Mubarak nor as ineffective as that of Morsi. 'We want something new', they said. The differentiation was along age and demographic lines. In the two focus groups with middleaged Christians in the rural village of Al Amoudein, participants emphasised that they would only feel more secure if the security apparatus took the same form as that under Mubarak.

The focus groups that rejected a return to a Mubarak-style police state emphasised the need for a system that would not be oppressive to the people but would nevertheless eliminate the threat of the Muslim Brothers. In one focus group, when asked 'what would you do if you were president?', the two most popular responses were 'to rid the country of the Brothers and to institute security that would not persecute the people', and 'the most important thing in my opinion would be to instate someone with an iron hand and who would not persecute the people'. However, these were not voices who wanted to simply hand over power to someone strong - they also wanted to be able to remove officials who did not deliver on jobs, education, sewage, garbage, etc.

It is important to note that for the time being many young people see the new surveillance mechanisms being introduced, such as body-checking every person and verification of their identities at different traffic points, as quite acceptable, in order to allow the authorities to uproot 'undesirable elements'. Also noteworthy is that Coptic males experience far less harsh and intrusive police checks than their Muslim counterparts (the police are able to identify their religious identification from their ID cards). This is because the police don't see them as a threat to national security, being Christian, so they are not targeted. Hence one of the unintended outcomes of the resurgence in police activities is that Coptic men are not being targeted - and in fact they feel protected by the stringent new security regulations.

However, some members felt uncomfortable with that. One young man from Abou Qorqas announced: 'It is the Muslim Brotherhood today, but it may be us tomorrow'. Therefore, while Copts did to some extent benefit from the unintended consequences of a political cleansing of the Muslim Brotherhood, they were aware of the limitations of this as well. This could by no means be relied upon as an empowerment strategy because it did not emanate from a transformed security apparatus that became accountable to the people. What the young man feared in terms of security violations against Copts emanating from this lack of accountability was well founded: there were numerous incidents in 2013 and 2014 where the security apparatus violated the rights of Copts and used coercive measures to deny them justice in the face of sectarian violence (a key example is the police assault on individual houses in Nazlet Ebeid in Minya in 2014 after the residents had protested in front of the police station about the disappearance of a Coptic woman). 


\subsection{National and territorial insecurity associated with the threat of terrorism}

The context in which Egyptians were responding to their own individual vulnerabilities was one of a region in complete disintegration, where there are collapsing states everywhere. To the east, Libya is in civil war and its borders are porous to terrorist activity. To the west, Syria is in a state of civil war and a portion of it is already occupied by ISIS. Further to the west, Iraq, which once had the second largest army in the region, is partly occupied by ISIS, and the rest of it is under a dysfunctional and incompetent government. To the south, Sudan has already been split into two countries after Western intervention. The perception that Egypt itself may lose part of Sinai to ISIS sympathisers was a threat that seemed very real.

As acts of violence against the new regime were instigated by the Muslim Brotherhood - a response to the overthrow of their president and his incarceration - the government launched an assault on its supporters, banned the movement and dubbed it a terrorist group and a threat to national security. During the first year after the overthrow of Morsi (July 2013 to May 2014), the question of whether reconciliation was the right pathway to end violence and instil a sense of security was being internally debated. Among those who had participated in the revolts of June 2013 against Morsi's regime, their opinions revealed no clear-cut relationship between reconciliation and violence (a major source of insecurity). Participants were asked the same question in three different ways. In all three cases, the answers suggest that these citizens are not prepared to accept that their security lies in pacifying the Muslim Brotherhood, with a slightly higher resistance to reconciliation on the part of Christians.

Table 3.3 Opinions on reconciliation with the Muslim Brotherhood (\%)

\begin{tabular}{|c|c|c|c|}
\hline & Muslim & Christian & Total \\
\hline \multicolumn{4}{|c|}{ Do you agree with the idea of reconciliation with the Musilm Brotherhood? } \\
\hline YYes & 21.9 & 8.1 & 18.1 \\
\hline No & 78.0 & 91.9 & 81.8 \\
\hline Did not answer & 0.1 & 0.0 & 0.1 \\
\hline Total & 100.0 & 100.0 & 100.0 \\
\hline \multicolumn{4}{|c|}{ If there is no reconciliation, do you think violence will increase? } \\
\hline Yes & 67.9 & 56.5 & 64.5 \\
\hline No & 32.1 & 43.5 & 35.4 \\
\hline Did not answer & 0.0 & 0.0 & 0.0 \\
\hline Total & 100.0 & 100.0 & 100.0 \\
\hline \multicolumn{4}{|c|}{ If there is reconciliation, will violence decrease? } \\
\hline \begin{tabular}{l|l} 
Yes \\
\end{tabular} & 32.0 & 26.9 & 30.6 \\
\hline No & 67.5 & 72.9 & 69.0 \\
\hline Did not answer & 0.5 & 0.2 & 0.4 \\
\hline Total & 100.0 & 100.0 & 100.0 \\
\hline
\end{tabular}

This sense of insecurity was compounded by Copts' suspicion that the West wanted to bring down the Egyptian state and that the Western press was used to suggest that the 30 June revolt was a coup rather than a revolution. In all the focus groups, whether in Minya or in Cairo, people said they responded to Al-Sissi's request for a mandate to take action against the Muslim Brotherhood because they wanted to show the world that the 30 June events were a people's revolution. By participating in the street parade to give Al-Sissi the mandate to quell the Brothers, they were making two statements: first, that they support the military obliteration of the Muslim Brotherhood and second, sending a 'message to the West'. In Egypt there was always a widely pervasive view of the Copts as supporters of the West on account of the assumed common religious identity (premised on the belief that the West is Christian).

In view of the fact that the Copts have always been perceived in the narratives of ordinary people as affiliated with the West through an assumed common Christian identity, the animosity expressed towards the US and the urge to resist it by taking to the streets was interesting. This shows that the vernacular is not only about parochial security needs and threats but also about the interface with global forces. The impact of those forces is felt very tangibly and their influence is not only on the cognitive level, but also behavioural. People felt 
propelled to take to the streets to demonstrate to the West that they rejected their vision of what happened in Egypt (coup) and what should happen (reinstatement of Morsi or at least the reinstatement of the Muslim Brotherhood).

Heba, a young woman in the urban town of Abou Qorqas in Minya, said that when she saw Al-Sissi on the television, calling upon people to go down, she wanted to go down to the streets that very hour: 'it is like someone is sinking and you need anything to hold on to, we were holding onto Al-Sissi'.

This deluge of responsiveness to, first, Al-Sissi as saviour and, second, the army as the guardian of the people against terrorism, was perplexing in the light of the Maspero Massacre of 2011 (see above). When asked what accounts for their support for Al-Sissi in the light of this bloody military record, the answers were highly revealing. Young people confided that while they had not forgotten about the army atrocities against the Copts in 2011 , they always have to opt for the choice that would incur least harm. It is a case of choosing the best of the worst scenarios available. As one member of the focus group pointed out, other than the military and the Islamists, was there any other viable third option? In their estimation, there wasn't. Hence, it was not a case of collective amnesia about the army as a source of insecurity, but a more realistic analysis of the power dynamics of the limited political choices that they saw as available to them. The army is not only less of a security threat than the Muslim Brotherhood, but also the only safeguard they have against Islamist militant groups taking over and exposing them to greater hardship.

On the other hand, while there is an endorsement of the protection against the 'terrorist threat' offered by the army and the police, many were concerned that national territorial security - in particular on the borders of Egypt - would become their primary occupation at the expense of protection for citizens in their everyday lives.

\subsection{Insecurity as complete hopelessness for the future generation}

One young man in Minya commented that 'the Muslim Brotherhood were not rejected because they were an Islamic group but because there was no indicator that the country was going forwards'.

However, the view that there was very little likelihood of the Copts maintaining a modicum of rights under the Muslim Brotherhood suggests that some of the insecurity emanated from a rejection of the possibility of long-term survival under the ideological banner of Islamism. Certainly some of the fears emanated from rumours about what might happen if the Islamists were empowered, for example Christians would be shunned and restrictions on their worship introduced and women made to cover their hair. But what was particularly interesting is that this insecurity was projected into the future. Middle-aged Coptic women in both urban and rural contexts talked about their anxiety not being for the present but for the future of their children, in particularly that of their sons.

This fear for the future emanated partly from their lived experience under the Muslim Brothers but it was also identity-based, deriving from a fear of a reversion in the modicum of status and rights they enjoy in a political order where, theoretically at least, citizenship rights are not consistently and systematically mediated by religion. It is not surprising therefore that immediately after the fall of the Muslim Brotherhood, many women and men in focus groups expressed fears about the ultra-radical and conservative group, the Salafis, taking over.

In 2015, two years after the 2013 revolution, the fact that the Salafis seemed to be politically contained gave many hope that it would not be a case of swapping one Islamist rule for another. However, in focus groups, hopelessness was replaced with hope for prospects of achieving full equality. In other words, the sense of insecurity was replaced with a sense of minimal insecurity. The word consistently being used in these conversations was that this 
current situation is ahwam, suggesting that their current predicament pales next to the previous one. Herein lies the key to understanding the great disconnect between authors who speak of Copts not enjoying their rights after the 2013 revolution and the Copts' own way of understanding reality. By decrypting the vernacular, it becomes clear that the Copts have no illusions that the change of regime will rid the country of religious discrimination, but it offers, at least, the chance that it will be better than anything they had experienced and hoped for under the Brothers. Two comparisons may perhaps help in further illuminating this. The first is the revolution of 2011, which brought hope of 'bread, freedom and social justice'. In that sense, the political choice of the people to support the revolution emanated from aspirations for the fulfilment of their citizen rights. But for the Copts the political choice to reject the Brothers and support Al-Sissi emanated from aspirations to suffer fewer citizenship violations and experience less insecurity, as opposed to aspirations to acquire more rights.

Another insight into the security/insecurity interface is offered in the differential way in which the young women in Minya (focus group 2013) spoke about the future. All the young women in the group agreed that the change of regime did not bring a massive improvement in women's vulnerability to sexual assault in public spaces. However, they said that they do hope that it may improve in the future - more so, they argued, than the prospects of future improved status for Copts: 'It will take a lot more than a revolution to change that', they said.

However, when the discussion moved on to what would make the future better for the Copts, there were some recurring themes across all the focus groups, irrespective of age, gender or geographical location. All emphasised the realm of education as critically important for building a new conscience that challenges fanaticism. They all also emphasised the importance of the economy and improved security for all Egyptians. This list of desired changes is interesting in that they are not measures that focus on the position and status of Copts (such as better representation in politics or more churches) but interventions aimed at the population at large, whose unintended outcomes would be beneficial to all. The policy implications here are not that it is not a priority for the government to redress gaps in inequalities in representation and inhibitions on freedom of worship, as these are needed as citizenship rights. It is rather to draw attention to how the quality of daily interactions and relations is so crucial for their cognitive identification of how well (or not) Copts fare as Christians among Muslims or as citizens bound by a common Egyptian identity.

Table 3.4 Do you expect violence in the next two years will... (\%)

\begin{tabular}{|l|l|l|l|}
\hline & Muslim & Christian & Total \\
\hline Increase & 20.3 & 11.4 & 17.7 \\
\hline Stay the same & 9.8 & 8.7 & 9.4 \\
\hline Go down & 27.2 & 38.4 & 30.4 \\
\hline Do not know & 42.8 & 41.3 & 42.5 \\
\hline Do not answer & 0.0 & 0.2 & 0.0 \\
\hline Total & 100.0 & 100.0 & 100.0 \\
\hline
\end{tabular}

\subsection{Security/safety as peaceful harmonious living with the other}

In the focus group comprising Muslim and Christian women facilitated by two facilitators, a Christian and a Muslim, in November 2013, a very intense confrontation happened, using very vernacular ways of alluding to deeply divisive issues. There was a great deal of subtext, and as the conversations progressed, two camps emerged, one Muslim and one Christian. However, they were also holding each other's 'religious community' accountable for what they saw as infringements that had created rifts between them. One of the sites for this was the role of mosques and churches in their communities.

Zeinab (Muslim): The role of men of religion is important for calming people and propelling them to love each other. 
$\boldsymbol{A}$ (Muslim): Their role is important in the mosque and the church so that they would implant in children good mores like love and tolerance and therefore the child would be raised from an early age to be good.

M (Muslim): They should direct people in religious affairs and not politics and he should not direct someone to be with this party or that.

$\boldsymbol{S}$ (Muslim): Their role is important because they should be to calm things down even if there is fitna, they should calm things down. During the hijra, the person who directed the Prophet to the hijra was a Christian.

$\boldsymbol{A f}$ (Christian): Their role is very influential on people. Here there was a sheikh who used to say 'Rise You Muslims, see what the infidels are doing!' Of course lots of people responded and were mobilised against the Christians. Me too, if I went to church and the priest said to me something to this effect, I would be loaded [mobilised].

$\boldsymbol{H}$ (Christian): I wish Al Azhar [institution] would play a better role than this and would play a stronger role.

MR (Christian): My opinion is that the church and mosque should get out of politics and do religion only.

A: The church should be out of politics and teach religion only.

$\mathrm{S}, \mathrm{H}$ and $\mathrm{A}$ all agree.

Without directly pointing fingers, each party was indirectly calling the other's religious institution to account for inciting sectarianism. The Christians were holding the sheikh in the mosque directly responsible for inciting people to attack them as 'infidels' and the Muslims were holding the church accountable not for mobilising the congregation but for failing to calm people down, calling upon Christians not to join the revolts against Morsi. The church had not responded to President Morsi's request that it call upon its congregations not to join the protests, saying that it does not intervene in politics, neither endorsing nor opposing their participation since it is an entirely individual decision. Muslims interpreted the reluctance to call upon people not to protest as indirect support for the revolution. These accountability mechanisms in the vernacular do not fall within the remit of conventional ways for people to hold to account a party they feel is responsible for wrongdoing. However, they do suggest a desire to engage with the real issues without becoming personally hurtful 'on account of all of us being neighbours'.

One of the facilitators confided afterwards that she was particularly worried that the discussions would spill over into open confrontation as the situation was becoming very tense. There were very clear opposing views based on political affiliations. The Muslims in the focus group who had previously supported the Morsi regime spoke about the harshness and cruelty of the police and how things had become worse while the Christians defended the police as being shot every day while trying to reinstate security. The Muslims spoke about how prices had increased dramatically after the overthrow of Morsi; the Christians spoke about how there were no more electricity cuts or severe shortages of staple items.

However, the discussions shifted towards common grievances. For example, when one Christian participant mentioned how her husband started restricting her mobility (as a consequence of the absence of security), a Muslim woman said her husband was acting the same way. After more than an hour of discussions, participants in the focus group ended with a desire to go beyond blaming each other and to put aside what had gone before and move forwards. The following are the closing words of that intense focus group discussion.

$\boldsymbol{A}$ (Christian) explained how she is teaching her daughter to respond to any queries about whether she is Christian or Muslim by telling the person we are all one, we all love each other.

MR (Christian) said that she hoped to be positive, to speak her opinion (openly) and teach her children to do likewise. 
$\boldsymbol{S}$ (Muslim): I want us all to go back to loving each other and make up with each other, I try and teach my children that.

Zeinab (Muslim): I would like to interact with everyone freely and he accepts me and I accept and win him over.

In a separate, all-Christian, focus group, security was interpreted as peaceful coexistence.

S: (I wish) that we live in peace and security/safety (amaan).

$M$ : to live in peace. The best thing is that we are now one hand. A lot of misfortunes have led to the injury and killings of Christians and Muslims.

$\mathbf{N}$ : I wish I could live in amaan and have good relations with Muslims because at the beginning I used to fear relating to them in all honesty and love, and this will come with amaan [safety/security]. Without peace, we won't be able to live.

These vernacular conceptions of security are critically important to understanding the desire for safety not as protection against the religious 'other' but as protection through embeddedness in harmonious relations with the religious 'other'. These are the relationships that are key to building relations that are not just characterised by tolerance and 'each to their own', but are interdependent and involve a degree of openness in relation to the 'other' without inhibition or fear. It is important to note that this reading of their security aspirations emanated from a particular juncture in time, through engagements with a set of relations. These need to be revisited through longitudinal research to examine how perceptions and interpretation of relations unfold.

\section{Conclusion}

This paper has presented an analysis of different Coptic groups' multiple experiences of the ebb and flows of securities and insecurities through a study of the vernacular forms of expression using focus groups. The study of vernacular securities has helped to uncover the multiple forms of citizen voice, agency and embedded relations on a local level. By examining these, one is able to make inroads in explaining what accounts for the discrepancy between the elitists' accounts of Copt support for authoritarianism and their political actions (such as revolting against authoritarian regimes). As Bubandt (2005) noted, vernacular securities represent a different ontological political project. The nine different meanings of security and insecurity articulated by Copts in this study show that they use the terms to mean far more complex and multidimensional features than those used by authors when they wrote about Copts and security.

By examining vernacular notions of security/insecurity, it becomes clear that, firstly, the Copts regard the source of sectarian assault as that of a pro-Islamist bloc avenging the overthrow of their president by a systematic backlash against the Christians. The discussion of the first and second dimensions of insecurity highlighted above showed in very tangible terms what ideological encroachment looks like on the ground. Copts' narratives clearly indicated that they perceived that discriminatory discourses and acts were driven by an ideology of Islamist supremacy that found its legitimacy, real or perceived, from an Islamist government in leadership. This was experienced as subordination, to the extent that Copts' subsequent exposure to a violent backlash by the Islamists after the overthrow of Morsi was interpreted as a price they had to pay for their liberation. Thus, another key to understanding complacency about continued security threats is in terms of the narratives of current insecurity being the cost of freedom from the most deeply felt threat of all - living in the shadows of an Islamist-inspired regime. One of the unintended outcomes of the overthrow of Morsi was the uprooting of particular forms of discriminatory practices that had infiltrated public life throughout his tenure. This reduced Copts' sense of alienation from the wider political community which was an important measure of their insecurity. 
However, if the Sissi regime engages in coalitional politics with Islamist forces and movements, there is likely to be, sooner or later, a violent reaction from the Copts, whether through local civil society actors or through organisations in the Diaspora. This is because the rejection of the Morsi regime was not only a rejection of the Muslim Brotherhood organisations but Islamism as a political movement ideologically. Even if Al-Sissi were to forge an entente with the Coptic Pope personally, this would not prevent Copts from collectively revolting in reaction to flagrant abuses of human rights, independently of the Coptic church leadership.

The Copts view the military intervention in support of the uprising against the Morsi regime as a heroic deed, and regard the army as liberators. However, this celebration of the army as saviour can neither be attributed to redress for past injustice nor the adoption of a pro-Coptic series of policies. Rather, it is a case of betting on the contender that is likely to incur the fewest insecurities. It is a reflection of the depth of animosity to Islamist rule and its vendetta against the Copts during and after its reign, rather than an adoration of the military. This can only be captured through a vernacular lens on people's adoption of a policy of minimal insecurity rather than maximum security.

The many nuanced understandings of the function of security revealed in the vernacular helps to unravel contradictory sentiments towards the state security apparatus. The security apparatus has been known since the Mubarak regime to be a key actor (in some instances the source of) in sectarian violence against Christians, yet the narratives of ordinary Copts refer to the desire for more security. This needs to be unpacked as it means a lot of different things.

One of the unintended consequences of the greater functionality of the police force is that Copts' vulnerability to religion-targeted forms of discrimination had decreased to a certain extent (though many forms of sectarian violence and assault continue). The role of the security forces in the political cleansing of the Muslim Brotherhood and broader pro-Morsi factions has also had the unintended outcome that Christian men at least are not being seen as a threat to the regime. In fact, the dubbing of that faction as terrorist has also benefited Christian men since they were targeted together with police and army personnel in the attacks. On the other hand, as expressed especially among young Copts, they are also acutely aware that a security apparatus that enjoys enormous power and is unaccountable can also target and oppress them, as they had already experienced in the governorate of Minya.

The limitations of the study of vernacular securities need to also be taken into account: perceptions are both space- and time-bound. The perceptions of the villagers in many locations in Upper Egypt who continue to experience kidnappings, demands for protection money and violence may ultimately be different from those of people in other parts of the country. Their perceptions are also time-bound in that major sectarian events, assaults or government practices could shift perspectives from one based on an overall favourable assessment of the situation compared to that of 2012, to one of anger and disillusionment if the government's policies severely undermine Christians' rights as Egyptian citizens and as Copts.

\section{Policy messages/issues}

\subsection{Policy messages on communal relations in Egypt}

5.1.1. The key message for future research on communal relations in Egypt, the status and situation of Copts, is the critical importance of capturing citizen voices and perspectives. This is crucial on two accounts: (i) to go beyond top-down elitist analysis that is often disconnected from the cognitive experiences of ordinary citizens; and (ii) to complement 
universalistic measurements that quantify numbers of incidents of violence, persons killed, property destroyed etc. with a broader set of indicators emanating from everyday experiences of violence and sectarian encroachments.

5.1.2 The study of the vernacular politics of securities/insecurities among Copts needs to be informed by an awareness that this is not only about alternative perspectives but an alternative ontological project that is informed by hidden transcripts, shared in certain spaces where positionality and trust are key.

5.1.3 While Copts' narratives are of minimising insecurities, the policy goal on all levels should be one of equal and full rights for all.

5.1.4 There is an inverse relationship involved in increased powers of Islamist political parties, movements, diffusion of ideology, formal or informal governance and the cognitive and material disempowerment of Copts as a religious minority. This also includes alliances or deals between the Egyptian government and any of the Islamist political forces on the ground across the ideological spectrum (i.e. those dubbed 'moderates' and those dubbed 'jihadist'). Any deepening of the Islamisation of politics and society is likely to increase tensions and open confrontation.

5.1.5 While the above policy is generic in its inference for all Copts in general, intersectionality of identity leads to differentiated experiences of insecurities. One of the most important for Coptic women is sexual harassment in public spaces. They share this with their Muslim counterparts, but also experience specific dimensions of this harassment as a consequence of being unveiled.

5.1.6 Addressing the problem of baltageya (thugs) in Egypt broadly will have a doubly positive impact on the everyday lives of Christians as they tend to be especially vulnerable to kidnappings, land occupations and protection demands.

5.1.7 Education at all levels, both formal and informal, is a key site for the perpetuation of sectarianism, sometimes reaching violent levels. This should be prioritised in a holistic way, not only in terms of curriculum but also the system in its entirety.

5.1.8 Hate speech against Christians, whether from mosques, satellite broadcasting or other forms of media, should be closely monitored. Where relevant, community naming and shaming of such practices should be encouraged.

5.1.9 Public transport is yet another key site for sectarian encroachments, and should be addressed by encouraging community naming and shaming, in addition to security measures to make public spaces safe for all.

\subsection{Policy messages for researchers, practitioners and activists' use of vernacular politics in heterogeneous societies with minority populations}

5.2.1 It is critically important to recognise vernacular politics and securities/insecurities not as offering a different toolkit for research, but as a different ontological project, which requires particular sensitivity to the positionality of the researcher, the specific contextual dynamics and the need for a different lens cognisant of the value of alternative understandings and narratives of the marginalised.

5.2.2 Engaging in the vernacular requires a recognition of the variations in each given group. Communities are often multivocal and variations can sometimes be identified across many identity axes, such as age, gender, geographic location, class, political orientation, family background, etc. Perceptions and understandings of security and politics are also, by default, varied and diverse. 
5.2.3 Building on the work of vernacular security studies scholars, we propose a framework that examines:

- how security/insecurity is understood;

- ilnternal variations in its understanding;

- $\quad$ its features in terms of the characteristics through which it manifests itself;

- $\quad$ the actors and network of relationships through which it is conveyed;

- $\quad$ its impact/outcome.

5.2.4 The capture of local agential perspectives on securities/insecurities is extremely useful for informing large sample surveys, complementing standard measurements of violence and insecurity with more specific ones that have been identified from within the local communities. If recurring themes/practices appear across different local spaces and with different groups as sources of and sites at which discrimination/persecution tends to manifest itself, these can then be integrated into the design of the study. The specific manifestations can become measurable indicators and integrated into large surveys.

5.2.5 In view of how fluid and dynamic agential perspectives of social relations are, it is critically important that this reality check (i.e. capturing their experiences) is undertaken on a regular basis, through longitudinal studies. Viewpoints and interpretations of reality change not only according to local-level factors, but also because national, regional and international dynamics can be interpreted in a particular way or have a specific ripple effect. Hence longitudinal studies are critical for capturing changes and shifts.

5.2.6 The process of capturing agential perspectives from below has revealed the importance of taking into account not only the material dimensions of inequalities (i.e. in access to resources and services) but also the non-material dimensions of how exclusionary ideology is experienced on the ground in day-to-day interactions, including those that are non-factual such as the circulation of rumours. This highlights the importance of not only experiences of discrimination but also the cognitive aspects of how people conceive and perceive of the threats on the ground, real or imaginary.

5.2.7 The positionality of researchers involved in capturing local perspectives on social dynamics and interactions is critically important in contexts where members of discriminated communities use 'dual talk', one aimed at the outsiders intended to be placatory and the other used among them, away from external gaze. The subtext here is important and can only be captured if there is a relationship of trust between the researcher and the participants of the study.

5.2.8 There is also the potential for informal mediation of restorative justice, if communicating this to the 'religious other' is done in ways that may be conducive to creating informal mechanisms of accountability and restorative relations.

5.2.9 While local agential perspectives may be captured at a local level, it is critically important to also examine ways in which they are linked to national and even global securities and insecurities. The generation of local-level knowledge should be seen as still embedded in broader security projects.

5.2.10 The examination of how people relate to security/insecurity should also seek to capture how these processes not only affect 'insider/outsider relations' but internal dynamics within members of the same group or community. These are key for capturing less conspicuous power relations that can be deeply influential. 


\section{References}

Amin, S. (2015) 'What Now for Egypt's Christians?', Al Ahram online, http://english.ahram.org.eg/NewsContent/4/0/120046/Opinion/0/What-now-for-EgyptsChristians.aspx (accessed 7 April 2015)

Bubandt, N. (2005) 'Vernacular Security: The Politics of Feeling Safe in Global, National and Local Worlds', Security Dialogue 36.3

BBC (2013) Interview with Tariq Ramadan, 'Tariq Ramadan: 'Egypt is Returning to a Mubarak Era',' August 20, www.bbc.co.uk/news/world-middle-east-23772361 (accessed 7 April 2015)

El Erian, G. (2014) 'The Egyptian State and the Religious Sphere, Carnegie Endowment for International Peace, 18 December', http://carnegie-mec.org/2014/12/18/coptic-churchand-politics-in-egypt

Fayek, M. (2015) 'Coptic Church Mixing Politics with Religion', Opendemocracy, 25 January, www.opendemocracy.net/arab-awakening/mina-fayek/coptic-church-mixing-politicswith-religion (accessed 7 April 2015)

Hamzawy, A. (2015) 'The Defining Lines between the Demand for Citizenship and Equality and Justification for Authoritarianism', Al Shorouk, 8 January (in Arabic), www.shorouknews.com/columns/view.aspx?cdate $=08012015 \& \mathrm{id}=80 \mathrm{~d} 49 \mathrm{~cd} 1-465 \mathrm{c}-$ 4f7e-9697-86c67c8ae41b (accessed 10 January 2015)

Hanna, T (2013) 'Supporters of the Uprooted (President) Attack the Church in Degla', Watani, 28 July 2013 (in Arabic), www.wataninet.com/watani Article Details.aspx?A=43278

Human Rights Watch (2013) 'Egypt: Sectarian Attacks Amid Political Crisis', Human Rights Watch News, 23 July, www.hrw.org/news/2013/07/23/egypt-sectarian-attacks-amidpolitical-crisis (accessed 7 April 2015)

Ibrahim, V. (2013) The Copts of Egypt The Challenges of Modernisation and Identity, London: IB Taurus

Jarvis, L. and Lister, M. (2013) 'Vernacular Securities and Their Study: A Qualitative Analysis and Research Agenda', International Relations 27.2: 158-79

Luckham, R. and Kirk, T. (2013) 'Understanding Security in the Vernacular in Hybrid Political Contexts: A Critical Survey', Conflict, Security and Development 13.3: 339-59

Rahouma, M. (2013) 'El Watan Records 64 Cases of Assaults on Churches and Copts in 12 Hours', El Watan (in Arabic), 15 August, www.elwatannews.com/news/details/260930 (accessed 8 December 2013)

Tadros, M. (2014) 'Settling after the Revolts? Egypt's Political Settlements and Violent Transition', IDS Evidence Report 57 (March 2014), http://opendocs.ids.ac.uk/opendocs/bitstream/handle/123456789/3545/ER57\%20Settli ng\%20After\%20the\%20Revolts\%20Egypt\%E2\%80\%99s\%20Political\%20Settlements \%20and\%20Violent\%20Transition.pdf? sequence=1 (accessed 13 April 2015) 
Tadros, M. (2013a) Copts at the Crossroads: The Challenges of Building an Inclusive Democracy in Contemporary Egypt, American University in Cairo Press and Oxford University Press of America

Tadros, M. (2013b) 'Devolving the Power to Divide', IDS Bulletin 45.5 in press, 2014

Tadros, M. (2013c) 'Copts under Morsi: Defiance in the Face of Denial', Middle East Report 267 (Summer 2013), www.merip.org/mer/mer267/copts-under-mursi (accessed 7 April 2015)

Tadros, M. (2012) The Muslim Brotherhood in Contemporary Egypt: Democracy Redefined or Confined? London: Routledge

Tadros, M. (2009) 'Vicissitudes in the Coptic Church-State Entente in Egypt', International Journal of Middle East Studies 41.2: 269-87

Waheeb, G. (2013) 'Supporters of the Uprooted (President) Surround Diocese in Beni Suef and Raise al-Qaeda flag on Marmorqos Church', Watani, 8 August 2013 (in Arabic), www.wataninet.com/watani Article Details.aspx?A=43675 (accessed 7 April 2015) 